\section{報告}

Technical Report

\section{インドの石炭 , 選炭状況と課題 *}

\section{遠 藤 $\quad-1$ 小 柳 伸 洋 $^{1}$ 原 田 道 昭 ${ }^{2}$}

\title{
Present Situation and Issues of Coal and Coal Preparation in India
}

\author{
by Hajime $\mathrm{ENDO}^{\mathrm{a} *}$, Nobuhiro KOYANAGI ${ }^{\mathrm{a}}$ and Michiaki HARADA ${ }^{\mathrm{a}}$
}

a. General Manger, Project promoting Dept. of Japan Coal Energy Center, 9F, Meiji Yasuda Seimei Mita building, 3-14-10 Mita, Minato-ku, Tokyo 108-0073 Japan (* Corresponding author E-mail: jimendo@jcoal.or.jp)

Indian economic growth is significant and real rate of economic growth continues $9 \%$ for several years. UN predicts that the population of India will outstrip China in 2030. Coal resources are placed more expectations on in rapid increase of demand for energy. On the one hand, Indian coal is characteristic having normally high ash content and difficulty of coal separation. This report introduces coal demand and supply, coal field, issues of coal utilization, road map and present movement of CCT, specialty of Indian coal and issues of coal preparation technology through JCOAL's study carried out more than 5 years.

KEY WORDS: India, Coal, Ash, CCT, Coal Preparation, Jig

1. はじめに

インドは中国に次いで経済発展著しく，実質経済成長率年間約 $9 \%$ こここ数年間続き， 2030 年には人口が 14.5 億に達し中国を追 い抜くと国連は予測している。急増するエネルギー需要のなかで, 石炭への期待が大きく, 一次エネルギーで $33.4 \%$, 発電量では $70 \%$ を占めている $\left(2005\right.$ 年度 $\left.{ }^{1)}\right)$ 。弊財団が自主事業, NEDO の 事業等により, インドでの日本の選炭技術導入可能性調査等を 5 年前から実施, また CCT (Clean Coal Technology) のインド研修生 受け入れ等で得られた情報をもとに, 選炭の観点からインドの石 炭を俯瞰する形で本稿を纏めた。

\section{2. 石炭需 給}

石炭省による石炭需給は Table 1 に示すように今後 10 年間の 平均伸び率は $9.4 \%$ ，需給ギャップを縮小すべく官民を含めた新 鉱開発を精力的に進めてきている ${ }^{1)}$ 。但し，この需給差は生産 側からの数字なので, 2006-07 年の 4,310 万トン輸入実績から見 ると楽観的な数字と思われ, 日本の石炭安定供給の観点から脅威 的な存在となろう。

鉄鋼産業が堅調に伸びる中で，原料炭確保が最優先課題となっ ていると同時に, Sponge Iron (海綿鉄) 生産に必要な低灰分一般 炭の需要も, 発電所石炭需要と同時に伸びている。また, 2016 年から CBM が計上されているのが注目される。

*2008 年 6 月 4 日受付 9 月 21 日受理

資源・素材 2007 (名古屋) にて発表, 内容を改訂

1. (財) 石炭エネルギーセンター 事業化推進部 担当部長

2. 普通会員 (財) 石炭エネルギーセンター 事業化推進部 担当部長

[著者連絡先 ] FAX: 03-6400-5207

E-mail: jimendo@jcoal.or.jp

キーワード: インド, 石炭, 灰分, CCT, 選炭, ジグ
3. インドの炭田

インドの石炭資源量は，インド地質調查所の 2007 年 4 月現在 における褐炭を除く合計は 2,573.8 億トン, そのうち確定埋蔵量 は 985.7 億トン (原料炭は $17 \%$ ，一般炭は $83 \%$ )。主な州別では Jharkhand 州 (37.7\%), Orissa 州 (17.8\%), West Bengal 州 (11.7\%), Chattattisgarh 州 (10.2\%) となっており，いずれもインド東部，南 東部の地域に賦存し，この 4 州で $77.4 \%$ を占める ${ }^{1)}$ 。

インドの炭田位置はFig. 1の黒く塗りつぶした部分で示す。また, 採掘方式は露天掘りが 87\%, 坑内掘りが 13\% である (2006-07 年 )。

Table 1 Forecast of coal demand and supply.

Unit: Mt

\begin{tabular}{l|r|r|r}
\hline & $\begin{array}{r}\text { 10th Plan } \\
(2006-07)\end{array}$ & $\begin{array}{r}11 \text { th Plan } \\
(2011-12)\end{array}$ & $\begin{array}{r}12 \text { th Plan } \\
(2016-17)\end{array}$ \\
\hline Total demand & 474 & 731 & 1,125 \\
Sponge Iron \& cocks & 43 & 68 & 105 \\
Electricity & 424 & 483 & 750 \\
Private power generation & 32 & 50 & 73 \\
Cement & 25 & 39 & 62 \\
Others & 50 & 91 & 135 \\
\hline Total supply & 431 & 680 & 1,060 \\
Coal India Ltd. & 361 & 521 & 664 \\
Singareni Collieries C Ltd. & 38 & 41 & 45 \\
Captive mine & 31 & 118 & 346 \\
CBM/CMM Eqvl. & & & 5 \\
\hline Gap between demand \& supply & -43.0 & -51.0 & -65 \\
Coking & -17.9 & -40.8 & -65 \\
Non-coking & -25.2 & -10.3 & \\
\hline Source :Coal Directory of India $2006-07$, & &
\end{tabular}

Source : Coal Directory of India 2006-07, MOC(2007) 


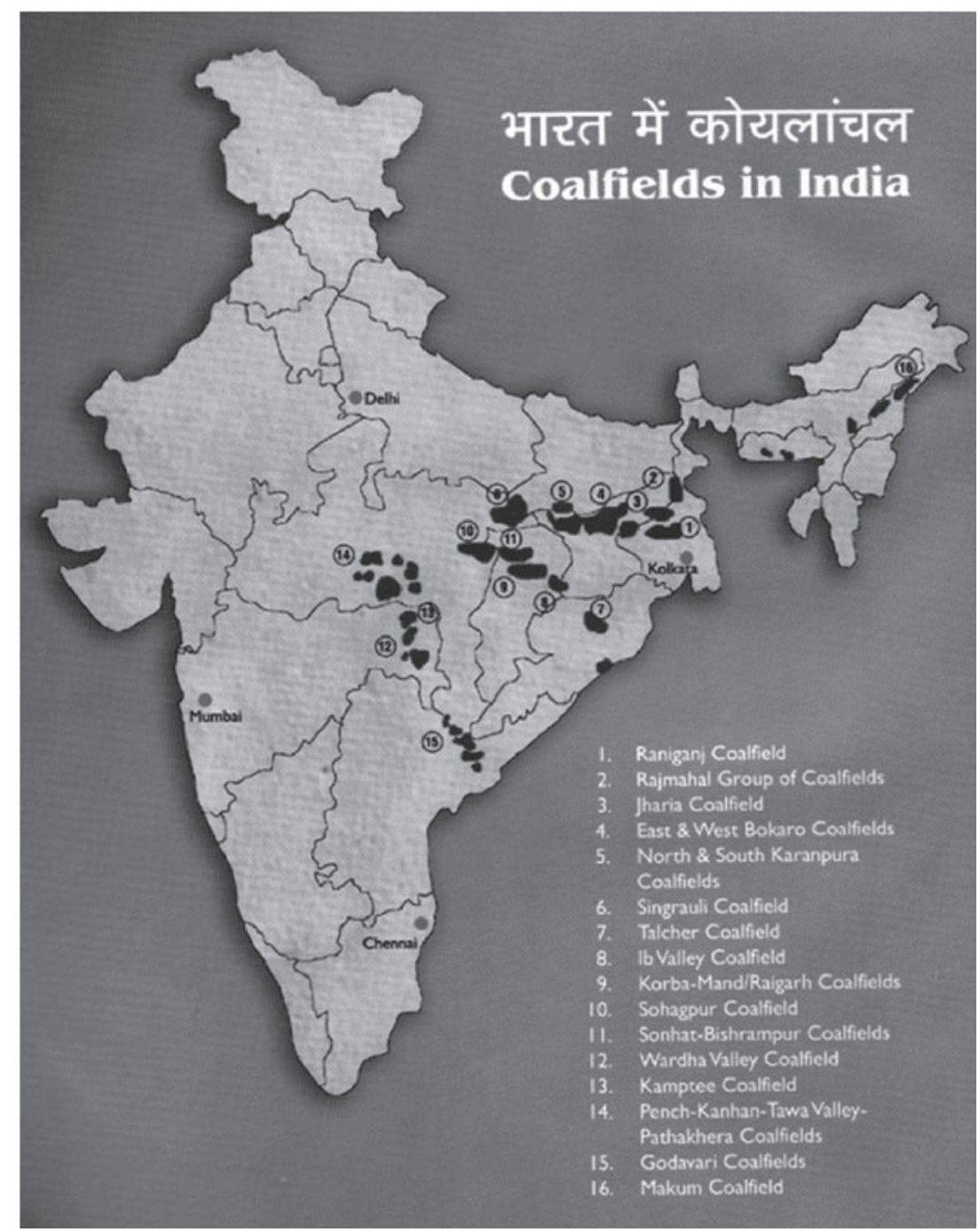

Fig.1 Coal field in India.

\section{4. インドの石炭利用状況と課題}

\section{4 - 1 石炭火力発電所}

2002 年 6 月 1 日より下記のいずれかの立地条件に入る石炭専 焼火力発電所は灰分 $34 \%$ 以下の石炭を使用寸る内容が環境森林 省から通達された。

(1)炭鉱から 1,000km を超える場合，(2)都市部，(3)環境影響を受 けやすい場所, (4)都市部污染が深刻な場所。なお, 適用除外は坑 口発電所, FBC, IGCC 技術を使用している火力発電所となっている。

インドでは石炭火力が 85 発電所 (2003 年現在), その中で, $34 \%$ の灰分規制の対象が 51 の発電所，残り 34 の発電所が規制 外である。特に, インフラ条件の良い海岸に近い発電所は輸入炭 との混炭による低灰分化の傾向が大きい。また，34\%の灰分規 制外の発電所でも, PLF (Plant Load Factor) 向上，保全コス卜低減 に向けて, 選炭した石炭のニーズは大きい。特に, 旺盛な電力需 要に対して, 新規発電所建設のオプションとして, 既存発電所の 低灰分の石炭の使用も検討されている。

一方，違反した場合は State Pollution Control Board から操業停 止命令が出されることもあってか，この通達の遵守状況は極めて 高く,インドの環境に対する姿勢をうかがわせる。

また，この灰分規制の背景には発電所の立地条件がある。イン ドは送電グリッドの分散化により，Table 2 に示寸様に，石炭生
Table 2 Distance wise requirement of thermal coal.

\begin{tabular}{|c|c|c|c|c|}
\hline \multirow{2}{*}{ Distance } & \multicolumn{4}{|c|}{ Transported Coal (Mt) } \\
\hline & 1996-1997 & $2001-2002$ & $2006-2007$ & $2011-2012$ \\
\hline $\begin{array}{l}\text { Mine Mouth } \\
\text { Power Station }\end{array}$ & 70 & 89 & 99 & 155 \\
\hline $\begin{array}{c}\text { Less Than } \\
500 \mathrm{~km}\end{array}$ & 54 & 51 & 55 & 70 \\
\hline $\begin{array}{c}\text { From } 500 \text { To } \\
1,000 \mathrm{~km}\end{array}$ & 35 & 30 & 43 & 60 \\
\hline $\begin{array}{c}\text { More Than } \\
1,000 \mathrm{~km}\end{array}$ & 55 & 95 & 148 & 216 \\
\hline Total & 214 & 265 & 345 & 501 \\
\hline
\end{tabular}

産箇所と発電所との距離が非常に離れているのが特徵である。石 炭価格は坑口原価の約 $2 \sim 3$ 倍が運搬コストになっている場合も あり，灰分低下による省エネルギー効果は非常に大きい。発電用 の低灰分化された石炭の運搬がインドの主要な石炭輸送機関である インド鉄道に利益をもたらすことは確実であると言われている ${ }^{2)} 。$ 将来，34\% 規制を更に引き下げる意見も出てきている ${ }^{2) 。 ~}$

$34 \%$ 灰分規制の根拠は上記の運搬コストと後述するインドの 高灰分の原炭性状によるもので, 選炭歩留と経済性, 資源有効活 用を検討した結果と推測する。

\section{$4 \cdot 2$ 石炭利用時の灰分}

インドではコークス用炭，セミコークス用炭，非コークス用炭 
Table 3 Grade of non coking coal ${ }^{4)}$.

\begin{tabular}{c|c}
\hline Grade & $\begin{array}{l}\text { UHV (Useful Heat Value, Kcal } / \mathrm{kg}) \\
\text { UHV }=8,900-138 \mathrm{X}(\mathrm{A}+\mathrm{M})\end{array}$ \\
\hline $\mathrm{A}$ & $6200<\mathrm{A}$ \\
\hline $\mathrm{B}$ & $5,600<\mathrm{B} \leqq 6,200$ \\
\hline $\mathrm{C}$ & $4,940<\mathrm{C} \leqq 5,600$ \\
\hline $\mathrm{D}$ & $4,200<\mathrm{D} \leqq 4,940$ \\
\hline $\mathrm{E}$ & $3,360<\mathrm{E} \leqq 4,200$ \\
\hline $\mathrm{F}$ & $2,400<\mathrm{F} \leqq 3,360$ \\
\hline $\mathrm{G}$ & $1,300<\mathrm{G} \leqq 2,400$ \\
\hline
\end{tabular}

Remarks; $\mathrm{A}=\mathrm{Ash} \% ; \mathrm{M}=\mathrm{Moisture} \%$ determined at $60 \% \mathrm{RH}$ at $40^{\circ} \mathrm{C}$

Table 4 Ash content of utilized coal in India.

\begin{tabular}{l|c}
\hline The Place of Coal Utilization & Av. Ash content (AD base) \\
\hline Coking Coal & 10 to 15\% \\
\hline Sponge Iron & $25 \%$ \\
\hline Thermal Power Station (a) & $34 \%$ \\
\hline Thermal Power Station (b) & $45 \%$ \\
\hline Mine Month Power Station & $50 \%$ \\
\hline Remarks; (a) shows TPS under the notice of Ash 34\% control by \\
Ministry of Environment \& Forests
\end{tabular}

それぞれに等級を付けて分類している。Table 3 はこの中の非コー クス用炭の等級を示しており, 最近は発熱量にUHV を使用する ことになっている。また, Table 4 では実際に使用している主要 灰分を示す。

また選炭後の精炭の灰分毎の利用方法を燃焼装置の技術導入之 併せて CFRI ( 中央然料研究所) が提案 ${ }^{3)}$ してる。インドでは 自国の資源の有効活用に高い関心を持っており, 従来一般炭の選 炭が普及しなかった理由の一つに, 選炭するとボ夕 (廃石) が発 生, まだ多少なりとも炭素分があるので, 捨てるのは無駄である というものである。その考え方を変えたのが前述した灰分規制で ある。従って, 今後選炭の普及が予想される中で, 捨てるものを いかに有効に利用寸るかが，新しい課題となってくる。

その一つの例は低品位炭としての選炭ボタによる鉱口発電であ る。特に, 海綿鉄用一般炭を選炭した後の選炭ボタには 50 \% 前 後の灰分 (約 $1,350 \mathrm{kcal} / \mathrm{kg}$ ) があり, これを IPP (independent power producer独立系発電事業者) に利用寸る発電計画が増加している。

\section{5. インドの CCT}

\section{$5 \cdot 1$ インドの CCT ロードマップ}

2006年に政府機関から発表されたロードマップをTable 5に示す。

\section{$5 \cdot 2$ ロードマップの主な石炭利用技術の状況}

(1) CBM (Coal Bed Methane)

- 1997 年政策決定, 探査活動開始。

・現在 26 の CBM 区画が割り当てられ, 総面積は $13,600 \mathrm{~km}^{2}$ 。 CBM 埋蔵量は $1,374 \mathrm{BCM}$ (Billion Cubic Meter), 潜在的生産能力 は38MMSCMD (Million Standard Cubic Meter per Day)。

・すでに 150 億円投資，UNDP (U.N. Development Program, 国連 開発計画) の支援で進行中。

• 4 区画で商業化評価終了。確認埋蔵量は 6.24TCF (Trillion Cubic Meter)。2007 年から生産開始予定。

- CBM の生産量として, 既に石炭省は 2012 年には石炭換算 5 百万トン, 2017 年 15 百万トン, 2022 年 25 百万トンを供給計 画に計上している。

(2) CMM (Coal Mine Methane) \& AMM (Abandon Mine Methane)

・2 炭鉱での試験を実施したが成功していない。今後とも挑戦す
Table 5 Road map of CCT in India

\begin{tabular}{|c|c|c|}
\hline $\begin{array}{l}\text { Ongoing \& near term }- \\
\quad(<5 \text { years })\end{array}$ & $\begin{array}{l}\text { Medium term- } \\
(5-15 \text { years })\end{array}$ & $\begin{array}{c}\text { Long term- } \\
(>15 \mathrm{y} . \text { and beyond })\end{array}$ \\
\hline $\begin{array}{l}\text { Coal preparation, improved } \\
\text { recovery, lower cost, rejects } \\
\text { disposal etc. }\end{array}$ & $\begin{array}{l}\text { Carbon sequestration } \\
\text { (Pilot scale) }\end{array}$ & $\begin{array}{l}\text { Carbon sequestration } \\
\text { (Commercial scale) }\end{array}$ \\
\hline $\begin{array}{l}\mathrm{R} \& \mathrm{M} \text { for improvement in } \\
\text { power plant performance }\end{array}$ & $\begin{array}{l}\text { Zero Emission Technologies } \\
\text { (ZETs) } \\
\text { (Pilot scale) }\end{array}$ & $\begin{array}{l}\text { Zero Emission Technologies } \\
\text { (ZETs) (Commercial scale) }\end{array}$ \\
\hline $\begin{array}{l}\text { Economy in coke } \\
\text { consumption in steel } \\
\text { plants-CDI, Stamp } \\
\text { charging, energy recovery } \\
\text { coke ovens. Similar steps } \\
\text { initiated by cement and } \\
\text { other coal-based industries }\end{array}$ & & \\
\hline $\begin{array}{l}\text { FBC, Super-critical power } \\
\text { plant boilers, IGCC } \\
\text { (Demo-unit) }\end{array}$ & $\begin{array}{l}\text { IGCC, PFBC, } \\
\text { Ultra-supercritical power } \\
\text { plants }\end{array}$ & $\begin{array}{l}\text { IGFC, Hydrogen fuels from } \\
\text { coal }\end{array}$ \\
\hline $\begin{array}{l}\text { Enhanced energy recovery } \\
\text { from coal: CBM, CMM } \\
\text { etc. } \\
\text { (Pilot scale) }\end{array}$ & $\begin{array}{l}\text { Enhanced energy recovery } \\
\text { from coal: CBM, CMM } \\
\text { etc. (Commercial scale) }\end{array}$ & \\
\hline $\begin{array}{l}\text { Coal liquefaction } \\
\text { (Pilot scale) }\end{array}$ & $\begin{array}{l}\text { Coal liquefaction } \\
\text { (Commercial scale) }\end{array}$ & \\
\hline
\end{tabular}

Source : Executive Summary of CCT imitative, DST, GOI, 2006

Table 6 Depth wise Geological Coal Reserves as on 1.1.2005.

\begin{tabular}{c|r|r|r|r|r}
\hline Depth & Proved & Indicated & Inferred & Total & \multicolumn{1}{c}{$(\%)$} \\
\hline $0-300 \mathrm{~m}$ & 71.0 & 66.5 & 15.0 & 152.5 & $62 \%$ \\
\hline $300-600 \mathrm{~m}$ & 6.5 & 39.5 & 17.0 & 63.0 & $25 \%$ \\
\hline $0-600 \mathrm{~m}$ (Jharia) & 14.0 & 0.5 & 0.0 & 14.5 & $6 \%$ \\
\hline $600-1,200 \mathrm{~m}$ & 1.5 & 10.5 & 6.0 & 18.0 & $7 \%$ \\
\hline Total & 93.0 & 117.0 & 38.0 & 248.0 & $100 \%$ \\
\hline
\end{tabular}

る計画を持っている。

(3) UCG (Underground Coal Gasification, 地下ガス化 )

• Table 6 に示すようにインドの石炭総資源量の中でかなりの割 合が深度，炭層賦存条件等から経済的に採掘不能と考えられて おり，それを対象に地下ガス化が検討されている。

- 対象: Gujarat 州地域の深部第 3 紀の石炭鉱床は 1,230 億卜ン。 UCG の研究開発には世界的にも好機と見ている。

・UCG の環境課題として, 地下水污染, 地盤沈下が挙げられて いる。

・APP (Asia Pacific Partnership) のタスクフォースにより，豪州が 積極的に協力している。

・UCG プロジェクト

Rajasthan 州 Barmer 市の GAIL で, カナダ企業と USG 契約締結。 その他, 下記に示寸国営石炭会社, 公団, 民間が実施に向けて 積極的に活動している。

Coal India, Singareni Collieries Company, Neiveili Lignite Corporation, ONGC, Reliance, NTPV, BHEL,GMDC, GIPCL, GSPC, 特に 2007 年より UCG を開始した南アのマジュバ炭田の UCG には関心が高い。特にインドは英連邦の繋がりが強固で, R\&D の分野でも積極的である。

(4) CTL (Coal To Liquid， 石炭液化 )

・インド北東部の石炭鉱床は低灰分 $(8 \%)$ ，高硫黄分 $(1.5 \sim 3 \%$ ～５）。 この地域の天然ガスの探査と生産を行っている Oil India Ltd. は Duliajan にCTL パイロットプラントを設置, Phase I は成功して いる。

- 南アの SASOL 社も Oil India Ltd と準備研究中。

(5) IGCC (Integrated Gasification Combined Cycle) 


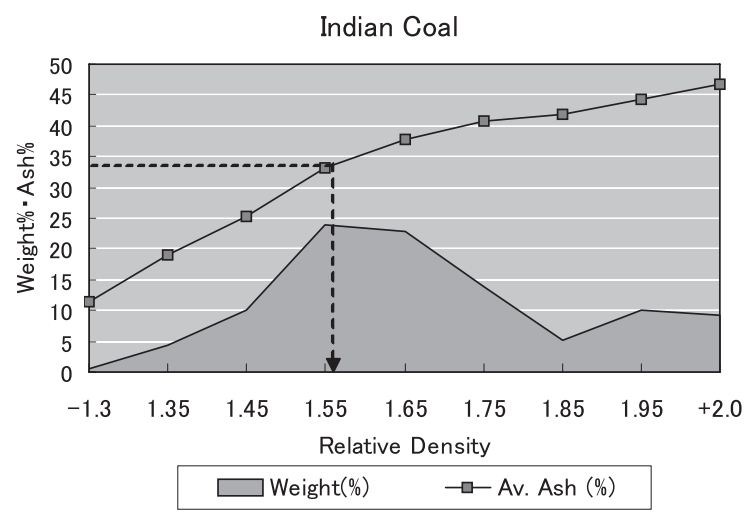

Fig.2 The analysis result of Float-Sink test of Indian raw coal.

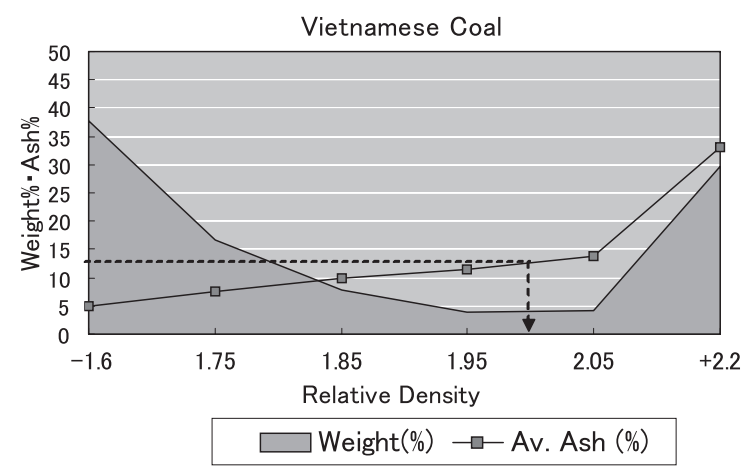

Fig.3 The analysis result of Float-Sink test of Vietnamese raw coal.

・BHEL 社が研究開発と実験終了。

・BHEL 社とAPGenco とが国内最大規模の $125 \mathrm{MW}$ IGCCを Vijayawada (Hyderabad から東南東 $230 \mathrm{~km}$ ) に建設に向けた MOU を2008 年 5 月に締結した。

\section{6. 選炭の観点からのインドの石炭}

\section{$6 \cdot 1$ インドの石炭の特徵}

インドの石炭はコークス用炭から亜瀝青炭, 褐炭に至るまで多 種にわたるが，ここではコークス用炭を除いた石炭について言及 する。

豪州，中国，米国の石炭と比較して，一般にインド炭は高濃度 の無機不純物を含有しており，低灰分の石炭が少なくなってきて いる。インド炭の一般的な特性には以下のようなものがある。

・石炭の灰溶融温度は高く，溶融しにくい特性を持つ灰である。

・石炭灰のシリカ・アルミナの比率は，スラグ粘性の面では好ま しい。一般にインド産石炭の $\mathrm{SiO}_{2} / \mathrm{Al}_{2} \mathrm{O}_{3}$ (シリカ・アルミナ) 比率は, およそ $2: 1$ で低粘度のスラグである。

・塩素分が低いので，塩素腐食はわずかである。

・一部の褐炭を除いて，硫黄分は約 $0.5 \%$ である。そのため，煙 道ガスの脱硫は問題にはならない。さらに, 灰含有率が高いた め, 灰組成によっては相当の硫黄分が灰に捕らえられる。

・高灰分を除けば，インド産石炭は環境に優しく燃焼に良い。

\section{$6 \cdot 2$ 原炭性状}

（1）選炭困難性一般にインドの石炭は選炭が困難であるの で選炭できないのではないかと言われているが，これは全くの誤 解であり，この紙上を借りて説明したい。「選炭が困難」と言う のは選炭の専門用語で near-gravity material が多いと言う意味であ る。これは分離比重に近似する比重の石炭が多いほど選別した後 に精炭, 廃石に迷い込み分が多くなり, 分離精度が低くなると言

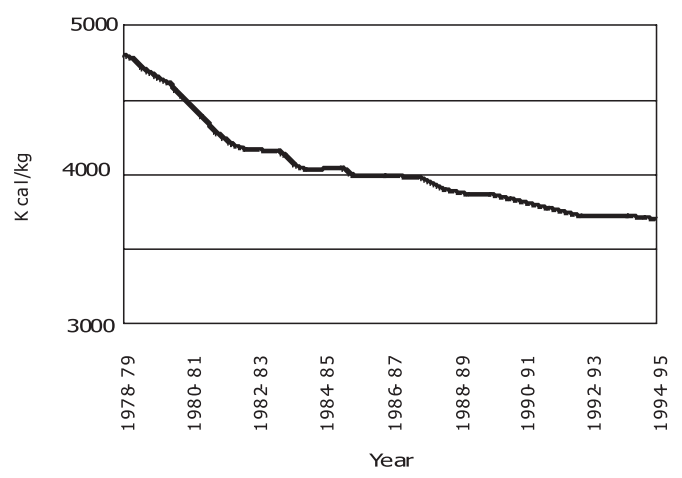

出典 "Review of Technology Requirements of the Coal Preparation Section in Indid" Department of Trade and Industry, Project Summary 263, Mr. Roshan Kamall

Fig.4 The tendency of coal quality of Indian ROM.

Particle Size .VS. Ash Content [IB Valley]

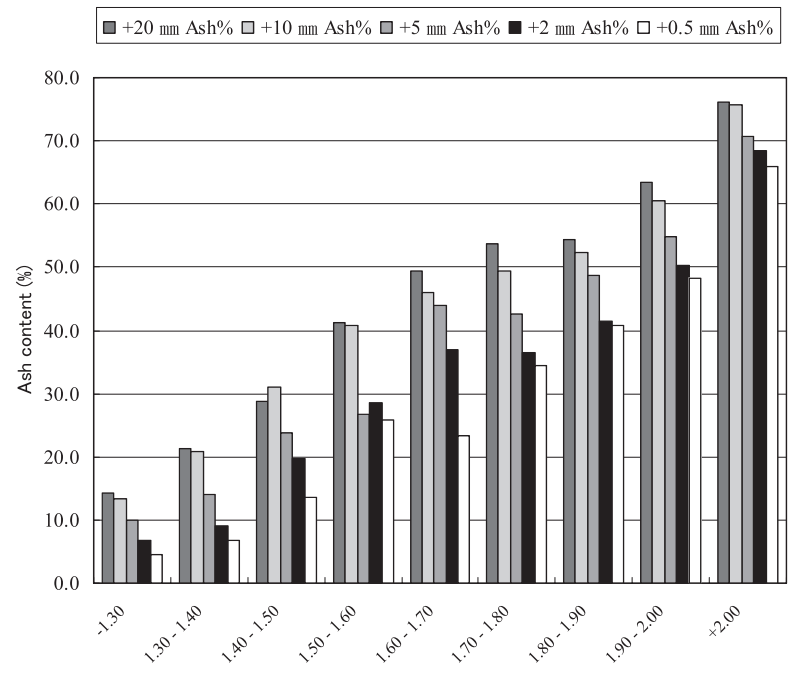

Fig.5 The result of sink-float test of IB Valley coal.

うことで, 選別できないという事ではない。

インド炭は豪州，中国，ベトナム炭と比べると，一般的に near-gravity material が多く, Dp ( 分離比重) \pm 0.1 比重範囲の重 量が $20 \%$ 前後で選炭している例が多い。

比較のために, Fig. 2 にインドの典型的な原炭 (ラジラッパ選 炭工場) と Fig. 3 に比較的選炭容易なべトナム (クワオン選炭工 場）の原炭の浮沈試験結果を示す。

Fig.2 のインド炭の場合, 平均灰分 34\% を産出するためには選別 比重が約 1.57 となり，その付近の石炭量は約 $25 \%$ になっている。 Fig.3のベトナム炭の場合, 平均灰分 14\% を産出するための選別 比重が約 2.03 となり, その付近の石炭量は約 $5 \%$ となっている。 その結果, インド炭の方が選別比重付近に石炭が多いので, 選別 誤差が大きくなる事が予想される。

またインド炭の場合，選炭歩留りは灰分 $30 \sim 34 \%$ で，60～ $70 \%$ が普通である。

（2）高灰分化 また原炭発熱量の変動を Fig. 4 に示す5)。高品 位炭の枯渇, 大型露天鉱の開発による増産体制, 薄層化, 挟み等 のため, 採掘原炭品位は悪化の一途を辿っているのがうかがえる。

また, 一時は露天掘り採炭現場で行われてきた選択採炭 (Select mining）と呼ばれる, 高灰分の石炭は捨て, 需要に合った品質の 
石炭の夕採炭する方法が見直され，現在は全て産出する方針に変 わってきているのも，原炭の高灰分化の一因になってきている。

新規開発の露天掘り条件は極めて良く, 剥土比 $1: 1$, 炭層厚み が数十 $\mathrm{m}$ というのもまれでない。高灰分を除くと羡ましい限り である。

（3）吸水性筆者らは選炭精度の確認のためにインドの石炭 サンプルを日本へ輸入，分析してその特異性に注目した。Fig. 5 はIB (イヴ) Valleyの原炭を粒度別に浮沈試験した結果を示すが, 粒度が小さくなるにつれ各比重毎の灰分が下がっているのがわか る。一般的に, 浮沈試験では一定の比重のもとでは多少の灰分の バラツキは有るが，ほぼ一定なのが普通だが，この様になるのは 極めて異例である。原因を調査したところ, 吸水性があることが 判明した。インドでは, サンプルを一晚水に浸してから浮沈試験 をすると聞き，納得した次第である。この種の石炭を選別する場 合は, 比重分離が基本の選炭技術では十分な検討が必要である。

\section{6 - 3 選炭工場状況}

（1）現状従来は原料炭の選炭が中心であったが, 原炭の悪化, $34 \%$ 規制等により, 近年選炭工場優遇政策もあって, 一般炭用 の選炭工場が急増してきている。

2003 年 10 月, CIL (Coal India Ltd) は, BOO (Built- OperateOwn) ベースに加え, 選炭工場建設に向けた土地無償リース等を 発表, CIL 傘下に 65 百万 $\mathrm{t}$ 年の新選炭工場建設を目指している。 2006 年 3 月現在の工場数, 設計処理能力は Table 7 の通りである。 現在の選炭率は全生産量の約 $25 \%$ となっている。

また 2007 年には CIL が需要家へ供給する全ての石炭を選炭す る方針が出され， 2012 年までに 5.2 億トンの選炭設備を整備する こととなり 1$)$ ，選炭工場新設に向け更に拍車が掛けられている。 最近, CIL は選炭工場を建設しないという従来の方針を変更, EPC (Engineering Procurement Construction) で建設する計画を打ち 出しており，自ら投資する形態である。

一方，国営を含めた発電会社も自ら選炭工場を建設する傾向も 出てきている。石炭利用者側が選炭工場を持つという, 嘗ての日 本の鉄鋼メーカーと同じように, 石炭の品質を自らが管理するこ ととなる。

（2）選炭技術原料炭の選炭工場はジグ選別, 重液選別, 浮 選機で低灰分の石炭を産出してきているが，新規に建設された一 般炭用選炭工場は設備投資, 運転コストの安いジグ水選機, バー レル選別機，流動層式選別機か，選別精度が高いがコストの高い 重液選別機を使用寸るかの 2 つ流れがある。筆者らは我が国の 選炭工場の経験から，インドの一般炭の選別にはジグ水選機を推 薦している。また, 原料炭選別の粗選にもジグの適用が考えられる。

\section{$6 \cdot 4$ 選炭課題}

一般炭用石炭の選炭工場の課題は

(1) 操業コストを含む選炭コストを安くすること。

(2) 分離比重付近に多くの石炭が存在する, 選炭しにくい原炭か ら精炭をより多く産出する。

（3）吸湿性がある原炭の場合, 吸湿性を考慮した選炭フローを検 討する必要がある。

(4) 選炭水のリサイクルが規則化されており, 経済的な脱水機の 選定が必要。
Table 7 Capacity of Coal preparation plant ${ }^{6)}$ (March, 2006)

\begin{tabular}{|c|c|c|c|c|c|c|}
\hline \multirow[b]{2}{*}{ Owner } & \multicolumn{2}{|c|}{ Coking } & \multicolumn{2}{|c|}{ Non-coking } & \multicolumn{2}{|c|}{ Total } \\
\hline & No. & $\begin{array}{l}\text { Capacity } \\
\text { (mt /year) }\end{array}$ & No. & $\begin{array}{l}\text { Capacity } \\
\text { (mt /year) }\end{array}$ & No. & $\begin{array}{c}\text { Capacity } \\
\text { (mt/year) }\end{array}$ \\
\hline Coal India & 12 & 20.10 & 7 & 20.20 & 19 & 40.30 \\
\hline SAIL & 2 & 3.50 & 0 & 0 & 2 & 3,50 \\
\hline Tata Steel & 4 & 6.42 & 0 & 0 & 4 & 6.42 \\
\hline Others (private) & 2 & 2.35 & 21 & 50.15 & 23 & 52.50 \\
\hline $\begin{array}{l}\text { Under Construction } \\
\text { (private) }\end{array}$ & & 0 & 3 & 16.50 & 3 & 16.50 \\
\hline Total & 20 & 32.37 & 31 & 86.85 & 51 & 119.22 \\
\hline
\end{tabular}

(5) 海綿鉄用の石炭を産出する場合, 選炭ボ夕発電に向け, 経済 性を考慮して精炭灰分を検討すること。

\section{$6 \cdot 5$ 日本の選炭技術の実証と普及}

弊財団はNEDOの事業による F/S 調査を通して, 日本が開発し, 日本, 中国, ベトナム，インドネシアで実績がある可変波形型ジ グ水選機 7-9) がインドの既存ジグと比較して, 石炭選別精度が高 いことを確認した。インドでの普及を目的としたモデル事業実施 に向けて現在準備中である。

\section{7.むすび}

インドでの最初の選炭工場のジグは日本製であったと聞いてい る。また, CFRI ( 中央燃料研究所) には今もなお 50 年程前の永 田製の試験用パイロットジグが稼働している。選炭技術は古くて 新しい技術であり，その国の原炭性状，およびインド人が好んで 使う Techno-economicに合った技術開発が今後とも要求されてい る。日本では選炭技術が有用資源回収に向けた選別技術として一 役を担っており，日々技術の向上が図られている。一方，我々は 日本で蓄積された選炭技術がインドの選炭し難い石炭に挑戦でき る日を待っている次第である。

謝辞＼cjkstart本稿を纏めるにあたり, 情報収集の機会を与えて頂い た経済産業省資源エネルギー庁石炭課，NEDO 環境技術開発部， 並びに情報収集にご協力して頂いたインドの石炭省 (Delhi), CFRI (Dhanbad)，CIL (コールインディア, Kolkata) 及び傘下の 炭鉱会社の CCL, MCL, SECL, MCL, BCCL, CMPDI (鉱山設計研 究所, Ranchi) に深く謝意を表する。

\section{References}

1) "India Coal Development Plan and its Effect on the World Coal Market" (NEDO report, March 2006) .

2) S.Bhattacharya, Ashim Kumar Maitra: "Rail Transport of Coal in India: Coal Quality and Economics", Proc XV International Coal Preparation Congress and Exhibition in Beijing, 2006

3) Ashok K Singh, Kalyan Sen, S.K. Hazra: "Challenge before Indian steel \& power industries-some programmatic solution", Proc PCC 2005-22 ${ }^{\text {nd }}$ International Pittsburgh Conference, USA.

4) Coal India Web site, http://coalindia.nic.in/

5) H. Endo and N. Koyanagi: "Look at Indian Coal Situation Through The Coal Preparation Technology" (Japan Coal Energy Center, 2007).

6) CMPDI, US-India Coal Working Group Meeting, 2006

7) Y.Iijima, Y.Shimoda, Y.Kubo, Y.Jinnouchi,S.Sakata, M.Konishi: "Improvement of Baum Jig into VARI-WAVE Type in Ikeshima Colliery", Proc X III International Coal Preparation Congress and Exhibition in Brisbane, 1998

8) H.Endo, J.Onodera, Y.Otaka: "Recent development activity of coal preparation technology in Japan", Proc X IV International Coal Preparation Congress and Exhibition in South Africa, 2002.

9) H.Endo, N.Koyanagi, Y.Kubo: "Upgrading Existing Coal Preparation Plant in Viet Nam by Transferred Japanese Cal Preparation Technology", Proc XV International Coal Preparation Congress and Exhibition in Beijing, 2006. 